\title{
Effects of Set-Point Substrate Moisture Control on Oomycete Disease Risk in Containerized Annual Crops Based on the Tomato-Phytophthora capsici Pathosystem
}

\author{
Johanna Del Castillo Múnera, ${ }^{1}$ Bruk Belayneh,2 John Lea-Cox, ${ }^{2}$ and Cassandra L. Swett ${ }^{1, \dagger}$ \\ ${ }^{1}$ Department of Plant Pathology, University of California, Davis, CA 95616 \\ ${ }^{2}$ Department of Plant Sciences and Landscape Architecture, University of Maryland, College Park, MD 20742 \\ Accepted for publication 1 April 2019.
}

\begin{abstract}
In containerized (potted) annual nursery and greenhouse crops, set point-controlled irrigation allows adaptation to increasing water insecurity by precisely reducing water inputs. A key factor influencing adoption is lack of information on disease risk. To facilitate adaptive water use, effects of set-point substrate moisture (SM) control on disease risk and water savings in containerized annual production were evaluated using the Phytophthora capsici-tomato pathosystem (a model system for water stress predisposition to pathogen infection), comparing outcomes of imposing midrange SM (15\% volumetric water content [VWC]) and low-range SM $(10 \%$ VWC) with well-watered $(20 \%$ VWC) plants. Reducing soil moisture to $10 \%$ VWC differentially reduced stem water potential $(P<0.05)$ and enhanced rate of wilt progress $(P=0.006)$ and root rot severity $(P=0.03)$ in $P$ capsici inoculated plants compared with noninoculated plants. Furthermore, incidence of fine root infections in inoculated asymptomatic plants was

greater under reduced SM (10\% VWC) compared with in well-watered plants $(P<0.05)$. Mild reductions to $15 \%$ VWC did not influence plant performance (root and shoot weights and plant height) or pathogen infection in either inoculated or noninoculated plants compared with well-watered plants and reduced water inputs by $17 \%$, indicating potential for reducing water usage without increasing disease risk. Furthermore, $P$. capsici inoculated plants had lower shoot biomass and greater root infection incidence when $15 \%$ VWC was applied to older compared with younger plants; the inverse was true for root rot severity, although root rot development was minor overall $(P<0.05)$. These results indicate that water use reductions pose disease risks, but there is potential to reduce water use and effectively manage plant pathogens in containerized production. Overall, this study indicates that physiological indices should not be solely relied on to develop water reduction methods.
\end{abstract}

The agricultural sector consumes nearly $70 \%$ of available fresh water worldwide (Fry and Martin 2005). With increases in water insecurity owing to a changing climate and depleted high-quality irrigation water in many parts of the world, agricultural demands are becoming unsustainable (Connor 2015; Piao et al. 2010; Vörösmarty et al. 2010). By 2050, agriculture will have to increase crop yields by $60 \%$ to supply the projected crop demands; in this time, it is highly likely that available fresh water will be substantially decreased (Connor 2015; Costa et al. 2007; Elliott et al. 2014; Howell 2001). One of the agricultural sectors that relies most heavily on the availability of high-quality water is the nursery and greenhouse industry (Fulcher and Fernandez 2013; Lamm et al. 2017). A single nursery in the peak of a growing season can consume from 14,000 to 19,000 gallons of water per acre per day (Fulcher and Fernandez 2013). Although this industry produces a diverse cross-section of crops from annual cut flowers to greenhouse vegetables transplants to landscape trees, as a heavily container-based system, there is a common need to identify strategies to adapt water use. We focused in this study on annual containerized production, which can be adapted to evaluate risks in perennial/woody crops.

Reductions in water use are crucial for sustainable crop production (Costa et al. 2007; Fedoroff et al. 2010). Studies in

${ }^{\dagger}$ Corresponding author: C. L. Swett; clswett@ucdavis.edu

Funding: This research is based on work that is supported by National Institute of Food and Agriculture, U.S. Department of Agriculture, SCRI award 014-5118122372 .

The author(s) declare no conflict of interest.

(c) 2019 The American Phytopathological Society various crops indicate that substrate moisture (SM) sensor-based irrigation scheduling can reduce water inputs by at least $50 \%$ in potted plant production without influencing crop quality or yields (Bayer et al. 2015; Belayneh et al. 2013; Chappell et al. 2013). Setpoint moisture control using sensor network-based irrigation offers optimal precision for managing irrigation inputs, minimizing many of the user errors associated with irrigation reductions, which can result in crop damage (Lea-Cox et al. 2013); as such, there is increasing interest in application in diverse containerized crops.

Development of crop-specific reduced irrigation practices has focused solely on evaluation of marketable yield impacts (Cameron et al. 1999, 2008; Davies et al. 2016; dos Santos et al. 2003). Based on these studies, irrigation inputs in potted plants can be significantly reduced without affecting plant yield or quality. However, nursery and greenhouse crop producers remain hesitant to adopt reduced irrigation approaches. This is in part because of perceived disease risks associated with reduced irrigation strategies (Knight et al. 2017; Lamm et al. 2017), particularly risks of exacerbating root rot diseases. In the absence of studies to assess the risks of moisture control on root diseases, it has been challenging to address these concerns and facilitate adaptive water use.

Diverse Phytophthora and Pythium species are among the most common root rot pathogens in nursery and greenhouse production, infecting a wide range of annual and perennial transplant crops as well as floriculture crops and woody ornamentals (Erwin and Ribeiro 1996; Leonberger et al. 2013; Parke et al. 2014; Schwingle et al. 2007; Warfield et al. 2008; Weiland 2011). SM can alter both pathogen survival and infection (Ristaino and Duniway 1989). Water availability is crucial to stimulate sporangia dispersal and differentiation as well as zoospores production, movement, and infection (Bernhardt and Grogan 1982; Granke et al. 2009; Hausbeck and Lamour 2004). As such, oomycete diseases are often favored by standing water, poor soil drainage, and excessive 
irrigation (Bryla and Linderman 2007; Hausbeck and Lamour 2004; Parke et al. 2014). Based on this, it seems plausible that reductions in SM could suppress pathogen survival and infection.

However, decreasing SM levels (i.e., increasing drought stress) can also predispose plants to oomycete pathogens, making them more susceptible to infection (Bostock et al. 2014; Cook and Papendick 1972; Duniway 1976; MacDonald 1982). Previous studies under water stress scenarios indicated that tomato inoculated with Phytophthora parasitica had higher disease severity than tomatoes grown under well-watered conditions (Ristaino and Duniway 1989). DiLeo et al. (2010) also showed that tomato seedling mortality significantly increased when exposed to salinity stress before inoculation with Phytophthora capsici. Based on these studies, significant reductions in SM could facilitate pathogen colonization of the host by increasing host susceptibility.

Diverse physiological studies have determined that the effect of reduced water inputs (e.g., irrigation deficit) varies depending on the plant developmental stage at which it is applied (Chen et al. 2013; Nuruddin et al. 2003; Patanè and Cosentino 2010). In previous studies, stress was enhanced and tomato yields were reduced when soil moisture deficits were deployed during flowering and fruit development stages compared with deficit application at a younger vegetative stage (Chen et al. 2013; Kuşçu et al. 2014). It, therefore, seems plausible that plant-pathogen interactions at lower SM levels might vary based on the plant age at which the stress is imposed.

To facilitate adaptive water use management in containerized (potted) greenhouse and nurseries production, this study was conducted to determine if set-point control tools to reduce SM pose a risk to oomycete pathogen infection and root disease development. The specific objectives were to (i) evaluate whether pathogen infection and disease development are affected by decreasing SM levels (volumetric water content [VWC]), (ii) determine whether water usage can be reduced without affecting plant disease, and (iii) determine whether timing and/or duration of reduced SM irrigation methods influence disease development. Because the influence of moisture and drought in the $P$. capsici-tomato pathosystem has been well studied (Bernhardt and Grogan 1982; Granke et al. 2009; Ristaino and Duniway 1989; Ristaino et al. 1991), it was selected as a reference containerized annual crop system to evaluate the effect of reduced SM levels. The intent of this study was to generate baseline information on oomycete disease risk factors associated with reduced set-point control irrigation regimes, which could be applied downstream to develop water-pathogen co-management strategies in specific nursery crop pathosystems. Although there have been many studies to evaluate drought-mediated plantpathogen interactions, this is one of the first to translate these

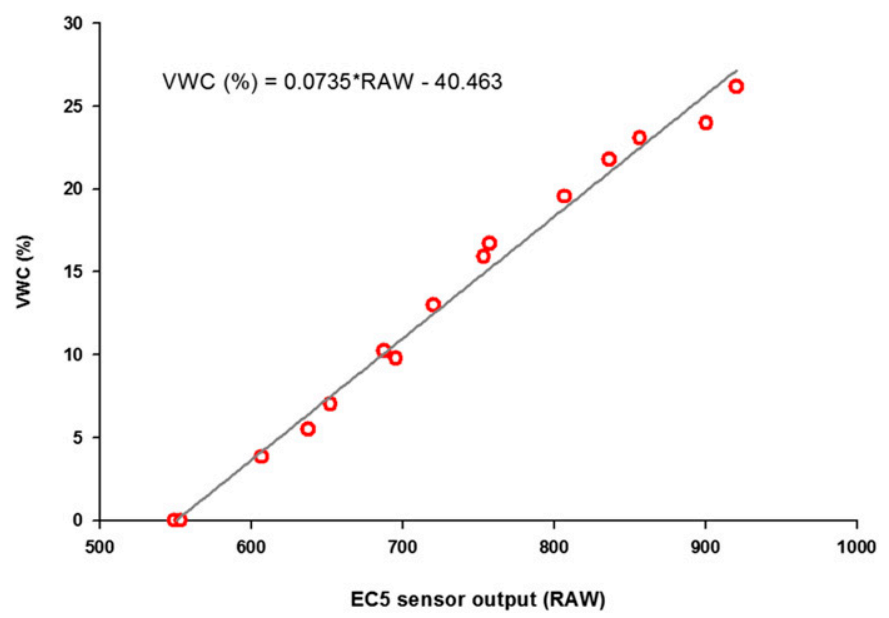

Fig. 1. Calibration curve for the sand media and EC5 substrate moisture sensor used to select irrigation treatments. VWC, volumetric water content. interactions to water scarcity adaptation scenarios and provide information relevant to irrigation management.

\section{MATERIALS AND METHODS}

Plant material. Seeds of Solanum lycopersicum 'New Yorker' were surface disinfested with $70 \%$ ethanol for $10 \mathrm{~min}$ and $50 \%$ sodium hypochlorite for $10 \mathrm{~min}$, and then, they were rinsed with distilled water (DiLeo et al. 2010). Disinfested seeds were sown on 50 plug trays containing a medium fine sand (Sakrete). Trays were placed on a bottom heat mat on a raised plant bench at the University of Maryland (UMD) Research Greenhouse Complex. Seedlings were maintained at 20 to $25^{\circ} \mathrm{C}$, with a photoperiod of $12 \mathrm{~h}$ per day; they were watered daily by mist and fertilized once a week with 100 ppm nitrogen constant liquid feed (19-6-18; Plant Marvel Laboratories Inc.) after seed germination.

Substrate calibration and sensor network irrigation system setup. A custom calibration was made for the sand media (Sakrete) using EC5 SM sensors (MeterGroup, Inc.) according to the procedure outlined by Cobos and Chambers (2010). For this study, sand was selected as substrate, because it does not cling to roots as would other substrates commonly used for containerized plant production, thus allowing accurate quantification of root weight, area, discoloration, and pathogen colonization. The VWC of the sand was measured using EC5 SM sensors. The procedure consisted of measuring the VWC of sand starting with dry sand and increasing moisture up to saturation point (Cobos and Chambers 2010). The resulting calibration curve (Fig. 1) coefficients were entered into the Sensorweb sensor control software (Mayim, LLC) used in the study to convert raw values from the EC5 capacitance sensors to corresponding VWCs.

A precision sensor network (Lea-Cox 2012) (Fig. 2) was setup to control irrigation for the experiments in the UMD Research Greenhouse Complex. Three irrigation laterals were laid out on each of two $5.8 \times 2.1-\mathrm{m}$ (length $\times$ width) raised benches. Corresponding laterals on each bench were controlled by individual nR5-DC nodes (Meter-Group, Inc.) that were attached to DC latching solenoids (Baccarra) on an irrigation manifold connected to a pressure controlled main water line. Irrigation was delivered to individual plants using Netafim yellow spray stakes with $300-\mathrm{ml} / \mathrm{min}$ output (Netafim USA) attached to the laterals using supply tubes.

Effect of reduced SM levels on Phytophthora root and crown rot. Experimental design. Based on the calibration curve for the substrate, three VWC levels were selected as SM treatment set points: $20 \%$ VWC (well-watered media), 15\% VWC (midrange SM), and $10 \%$ VWC (low-range SM). The experiment was arranged in a randomized complete block split-plot design, with two blocks on each of two benches, for a total of four blocks. Irrigation treatment was in the main plots, which were randomly distributed in each of the four blocks (Fig. 3). Inoculation treatment was in the subplots, consisting of eight inoculated and eight noninoculated plants randomly distributed within each main plot for a total of 32 plants in each $\mathrm{SM} \times$ pathogen treatment combination. The experiment was conducted two times.

Treatment application. Eleven-week-old plants were transplanted to 1-liter pots containing $3.1 \mathrm{~kg}$ of sand and watered daily during the first week. Then, the 12-week-old plants were transferred to raised benches, the SM treatments were initiated (20, 15, and $10 \%$ VWC), and plants were immediately inoculated. Inoculations were conducted with a single $P$. capsici isolate (SL897). This isolate was recovered from infected peppers from St. Mary's County, Maryland and identified by the internal transcribed spacer (ITS) sequence, with 99\% identity with $\mathrm{AB} 217670.1$. The sequence of the isolate SL897 used in this study was submitted to NCBI under the accession number KY819081. In addition, SL897 virulence was confirmed in preliminary studies in which inoculated tomatoes consistently displayed symptoms of root rot and wilt. To prepare inoculum, cultures were grown on unclarified V8 medium $(160 \mathrm{ml}$ of $\mathrm{V} 8,840 \mathrm{ml}$ of distilled water, $15 \mathrm{~g}$ of agar, and $0.15 \mathrm{~g}$ of $\left.\mathrm{CaCO}_{2}\right)$ at 
room temperature $\left(20^{\circ} \mathrm{C}\right)$. A zoospore suspension was prepared by flooding actively growing mycelia of 7-day-old $P$. capsici plates with $10 \mathrm{ml}$ of sterile distilled water. Flooded plates were incubated at $4^{\circ} \mathrm{C}$ for $45 \mathrm{~min}$ followed by $30 \mathrm{~min}$ at room temperature $\left(\sim 24^{\circ} \mathrm{C}\right)$. Released zoospores were harvested by pouring the zoospore suspension through cheesecloth. The zoospore concentration was estimated with a hemacytometer and adjusted to $1 \times 10^{6}$ zoospores per $1 \mathrm{ml}$ (Granke et al. 2009).

Ten milliliters of the zoospore suspension $\left(1 \times 10^{6}\right.$ zoospores per $1 \mathrm{ml}$ ) was decanted around the crown of each plant; $10 \mathrm{ml}$ of sterile water was applied to negative controls. Saucers were placed under the pots for $48 \mathrm{~h}$ and removed for the rest of the experiment. Experiment 1 was conducted from May to June 2016, and experiment 2 was conducted from June to July 2016. Disease development was monitored for 28 days. The daily mean air temperature ranged from 23 to $29^{\circ} \mathrm{C}$ during the first experiment and from 23 to $31^{\circ} \mathrm{C}$ during the second experiment, with a photoperiod of $12 \mathrm{~h}$ per day.

To monitor the substrate VWC in the root zone of plants, the EC5 SM sensors were inserted halfway up 1-liter pots filled with sand by cutting a vertical slit in the side of the container. The sensors were pushed into the sand through the slit with prongs oriented vertically. The medium was packed around the sensors to ensure good contact, and the slit then taped. The EC5 SM data were recorded on a 5-min basis using a combination of Em50R and nR5-DC radio data loggers (Meter Group, Inc.) and transmitted to the Sensorweb software (Lea-Cox 2012) (Fig. 2). Irrigation was applied whenever the average VWC of five EC5 sensors per treatment dropped below the corresponding set point. Irrigation duration was limited to $20 \mathrm{~s}$ per event to reduce leaching from the sand. Irrigation volumes applied to each treatment were measured using Badger flow meters (Model 25; Badger Meter Inc.) connected to the nR5-DC nodes.

Plant growth and fresh weight. Plant height was measured at 28 days postinoculation (dpi) as the distance from the foot of the plant (substrate line) to the base of the most axial leaf petiole. At the end of each experiment, plants were removed from the pots, roots were gently washed under running tap water, and total shoot and root fresh weights were measured separately for each plant.

Leaf water potential. At the end of each experiment, at predawn, the first fully developed leaf on the youngest shoot of each plant was detached for leaf water potential $\left(\Psi_{\mathrm{w}}\right)$ measurement using a PMS pressure chamber model 1000 (PMS instrument Co.). Leaves were placed on a pressure chamber with the cut end protruding through an airtight seal. Nitrogen pressure in the chamber was increased until free water appeared at the cut surface. Pressure readings (bars of pressure) were converted into megapascals as a means of quantifying leaf water potential (Buxton et al. 1985; Tyree and Hammel 1972).

Wilt development over time. Wilt severity was assessed at 7-day intervals from 7 to $28 \mathrm{dpi}$ using a rating scale that evaluated both abiotic (water stress-associated) and pathogen-induced wilt. Plants were visually assessed using a 1 to 5 scale, where $1=$ no symptoms,

\section{Local Irrigation Control}

\section{Production Area / Irrigation Zone}

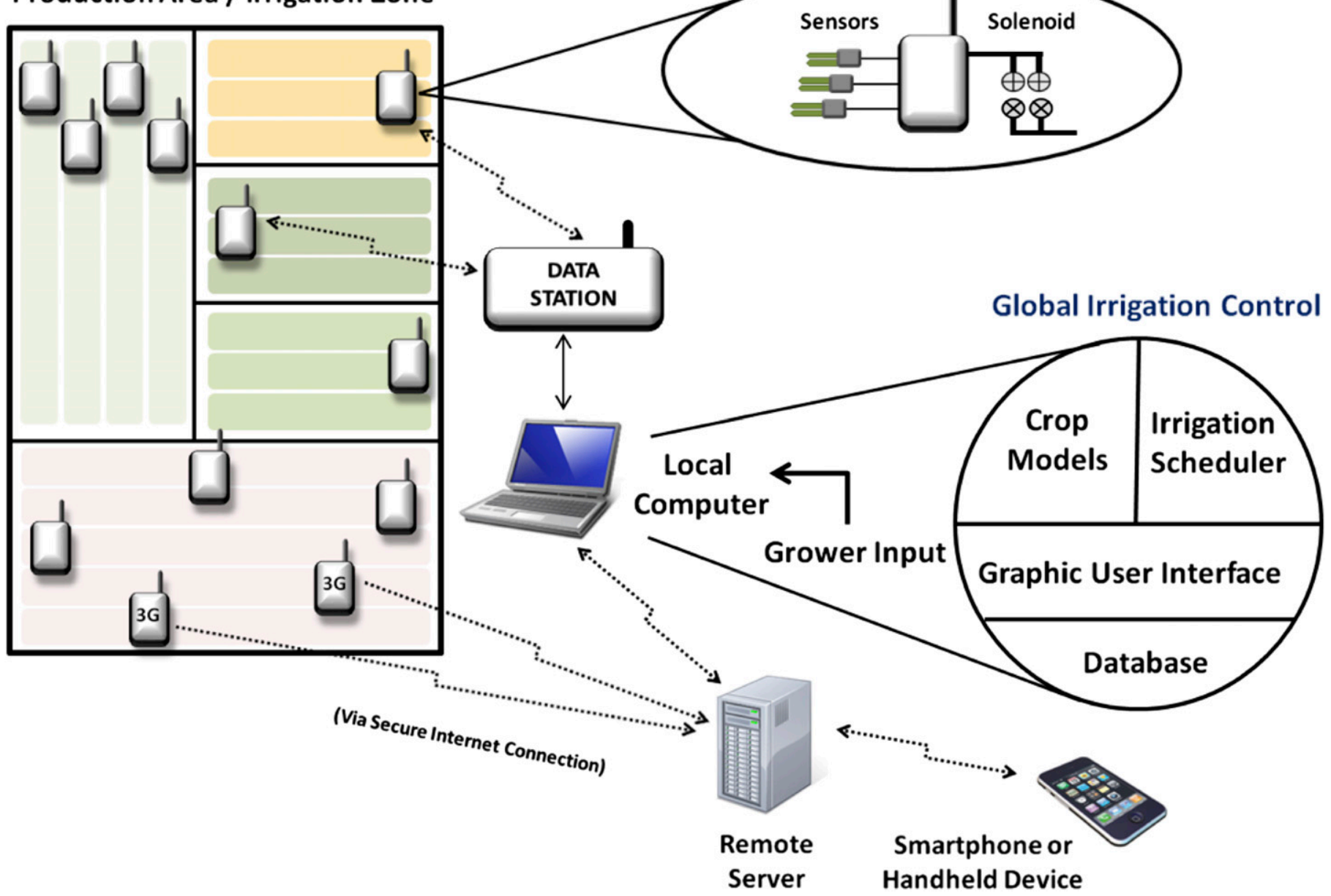

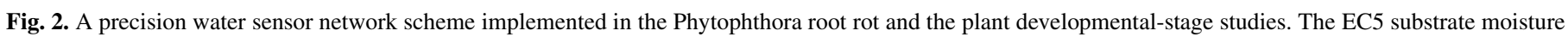

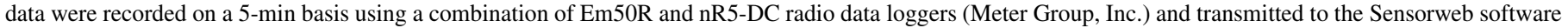
(Lea-Cox 2012). 
$2=1$ to $30 \%$ of plant wilted (minor wilting of the leaf tips), $3=31$ to $50 \%$ of plant wilted (leaf wilting is more pronounced), $4=51$ to $80 \%$ of plant wilted (major wilting of leaves), and $5=>80 \%$ of plant wilted or plant is dead (Quesada-Ocampo and Hausbeck 2010). The area under the symptoms progress curve (AUSPC) was estimated by inserting the symptom severity rating per plant over time into the area under the disease progress curve (AUDPC) equation (Shaner and Finney 1977). For this, the disease value was replaced by the symptoms value (AUSPC). The AUSPC can account for foliar symptoms that developed as a result of either the pathogen treatment (disease) or the irrigation treatment (water stressinduced abiotic wilt), which were both necessary to account for in this study.

Root area and discoloration. After washing, plants were visually assessed for the presence of lesions on the roots and the crown. The
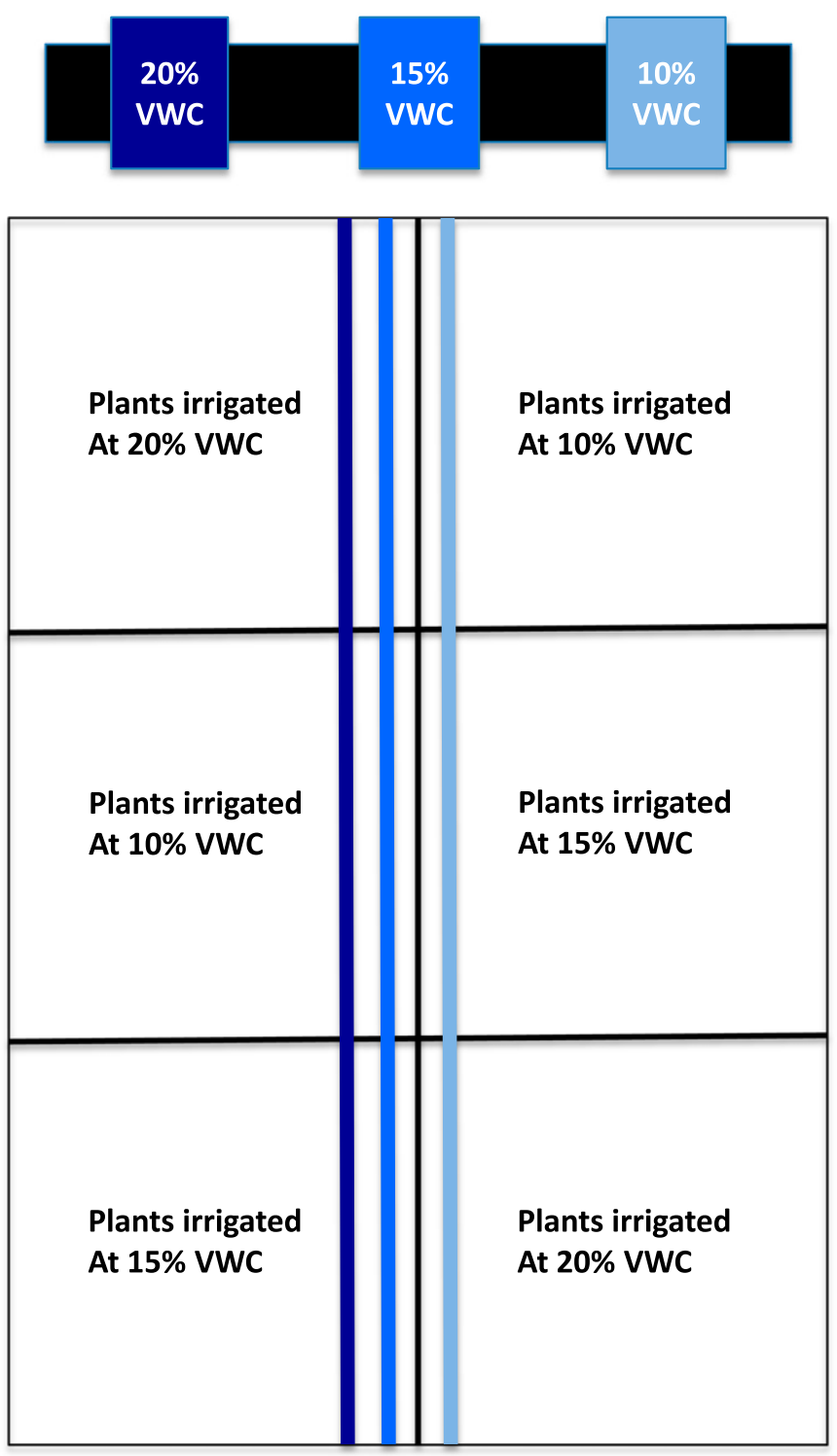

Fig. 3. Effect of reduced substrate moisture on Phytophthora root rot experimental design. Scheme of one bench implemented in the experimental setting. The experiment was arranged in a randomized complete block split-plot design with two blocks on each of two benches for a total of four blocks. Irrigation treatment was the main plot, and inoculation treatment was the subplot (not shown). Irrigation treatment plots were randomly distributed in each of the four blocks. Corresponding irrigation laterals on each bench were controlled by individual nR5-DC nodes (Meter-Group, Inc.) that were attached to DC latching solenoids on an irrigation manifold connected to a pressure controlled main water line. VWC, volumetric water content. total root area and the proportion of the root system discolored were estimated using the image analysis software ASSESS 2.0 (Lamari 2008). The discolored tissue area was calculated following a scale from 31 to 101 color hue. To estimate the total root area, $1 \mathrm{~cm}^{2}$ of a real-size ruler scale was calibrated in Assess 2.0, and the root area was measured (Del Castillo Múnera and Hausbeck 2016).

Pathogen colonization. On experiment completion, all of the inoculated plants from each irrigation treatment were evaluated for extent of pathogen colonization. Plants were categorized as symptomatic or asymptomatic based on the presence of root discoloration and aboveground root rot symptoms. A $10-\mathrm{cm}$ segment of one lateral root and any symptomatic plant tissue was removed from each plant, washed under running tap water, air dried, cut in 1-cm lengths, and placed on V8 medium amended with pimaricin ( $0.4 \mathrm{ml} /$ liter $)$, ampicillin $(0.25 \mathrm{~g} /$ liter $)$, rifampicin $(0.01$ $\mathrm{g} /$ liter), and pentachloronitrobenzene $(0.05 \mathrm{~g} /$ liter $)$. $P$. capsici emergence (presence/absence) was scored for each of the $101-\mathrm{cm}$ root segments per plant. The incidence of plant infection was quantified based on the percentage of plants from which $P$. capsici was recovered from one or more root segments. Extent of infection was quantified as the number of segments (of 10) from which $P$. capsici was recovered.

Isolates resembling $P$. capsici were initially confirmed by microscopic observations of sporangia, and mycelia was transferred and purified to V8 medium. All P. capsici-like isolates were further analyzed using PCR-based confirmation with the three PCR primers specific for $P$. capsici (CAPFW, CAPRV1, and CAPRV2) (Silvar et al. 2005). DNA was extracted from the isolates growing on V8 medium using the Prep Man Ultra Kit (Life Technologies). PCR reactions were implemented as described in Silvar et al. (2005) using 1× Go Taq green master mix (Promega) (Silvar et al. 2005); amplifications were performed on a C1000 Touch thermal cycler (Bio Rad). Amplicons were visualized on $1.5 \%$ agarose gel using Bio doc-it imaging system software.

Statistical analysis. Experiment and block were considered random variables, and SM and pathogen treatments were considered fixed variables. There was no difference among experiments, and there were no significant $\mathrm{SM} \times$ pathogen treatment interactions; therefore, data were pooled and analyzed together. Root area, root and shoot weight, leaf water potential $\left(\Psi_{\mathrm{w}}\right)$, plant height, plant decline incidence, percentage of root system discolored, infection incidence, and extent of root colonization were analyzed by analysis of variance (ANOVA) using the Proc mixed procedure of SAS 9.4 (SAS Institute Inc.). Plant was treated as the unit of replication (32 replicates per experiment; 64 for experiments combined) for all analyses except the incidence analyses, in which block was treated as the unit of replication (four replicates per experiment; eight for experiments combined). Residual normal distribution was tested using normality plots and the Shapiro-Wilk test. Percentage data were square root transformed before analysis; ANOVA was evaluated using type III test (Del Castillo Múnera and Hausbeck

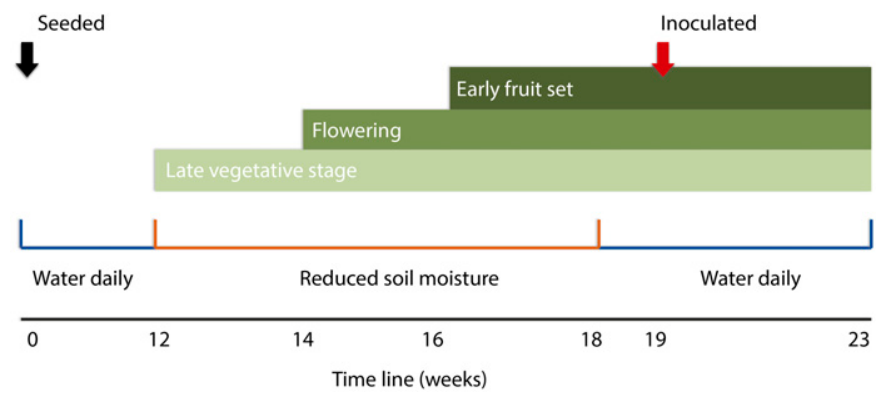

Fig. 4. Plant developmental-stage study setting. Sets of 16 tomato plants at late vegetative stage, flowering, and early fruit set were subjected to 15 or $10 \%$ volumetric water contents during 6, 4, and 2 weeks, respectively, and then, they were inoculated at 19 weeks; data were collected over a 28-day duration. 
2016; Swett et al. 2018). If ANOVA was significant for main effects or interaction terms, treatment means were compared using least square means significant difference (LSD) test at $\alpha=0.05$. The extent of root colonization in symptomatic and asymptomatic plants was analyzed conditionally for infected plants only. By excluding uninfected plants, conditional analysis provides a measure of the extent of colonization after the pathogen has overcome penetration barriers (McRoberts et al. 2003; Swett et al. 2016).

Disease severity data and AUSPC were analyzed using nonparametric analyses (Shah and Madden 2004) with the Proc rank procedure to estimate the midranks and Proc mixed SAS 9.4 for ANOVA-type statistics (SAS Institute Inc.). A significance level of $\alpha=0.05$ was used for all pairwise comparisons.

Effect of plant developmental stage on SM-pathogen interactions. Experimental design. Reduced SM was further evaluated for differential effects on disease when reduced SM was initiated at different stages of plant development corresponding to different durations under reduced SM. Effects were examined separately under two reduced SM conditions: 15 and 10\% VWC. Developmental stages consisted of (1) late vegetative (12-week-old plants under reduced SM for 6 weeks), (2) flowering (14-week-old plants under reduced SM for 4 weeks), and (3) early fruit set (16week-old plants under reduced SM for 2 weeks) (Fig. 4). Pathogen treatment consisted of (1) inoculated and (2) noninoculated. The experiment was arranged in a randomized complete block split-plot design, with two blocks on each of two benches, for a total of four blocks. Developmental-stage treatment was the main plot; the three developmental-stage main plots were randomly distributed in each of the four blocks. Pathogen treatment was the subplot; each subplot consisted of four inoculated and four noninoculated plants randomly distributed within each main plot for a total of 16 plants for each developmental stage $\times$ pathogen treatment combination within each experiment. The experiment was conducted twice.

Treatment application. Treatments were applied sequentially (Fig. 4). First, plants (propagated as described above) were placed under the target irrigation regime (15 or $10 \%$ VWC) starting at each of three different developmental stages corresponding to late vegetative (12 weeks old; treated for 6 weeks), flowering (14 weeks old; treated for 4 weeks), and early fruit set (16 weeks old; treated for 2 weeks) (Fig. 4). Irrigation treatments were applied until the plants were 18 weeks old. Plants were then well watered daily for 1 week. Thereafter, one-half of the plants in each developmental- stage treatment were inoculated, and one-half were not inoculated (Fig. 4). Inoculations were conducted after a return to well-watered conditions to evaluate the effects of the reduced SM treatments on host resistance. Of note, because timing of irrigation treatments varied both by developmental stage as well as by duration of the irrigation application, treatment effects on resistance could be because of differences in host development, reduced SM duration, or a combination of these.

Inoculations were conducted with infested millet to ensure disease development on mature plants. Based on preliminary studies, it was found that disease development was more pronounced when plants were inoculated with infested millet than with zoospore suspension. Inoculum was produced by adding 10 plugs $(1.5-\mathrm{cm}$ diameter, 1 week old) of actively growing mycelia ( . capsici isolate SL897) in V8 culture to mushroom bags (RJG Sales and Supply) containing $300 \mathrm{~g}$ of millet seeds mixed with asparagine $(0.24 \mathrm{~g})$ and water $(216 \mathrm{ml})$ that had been autoclaved twice (Del Castillo Múnera and Hausbeck 2015). The inoculated millet was incubated at room temperature under constant fluorescent light for 2 weeks and shaken every other day to evenly disperse the inoculum. Three grams of infested millet seeds were added into each of the $\sim 3$-cm-deep wells placed at evenly spaced intervals about $2 \mathrm{~cm}$ from the base of the plant, and the millet was covered by $\sim 2 \mathrm{~cm}$ of media. Negative controls remained untreated. Plants were maintained under well-watered conditions, and disease development was monitored for 28 days as described above. For both 15 and $10 \%$ VWC studies, the daily mean air temperature ranged from 23 to $30^{\circ} \mathrm{C}$ for experiment 1 and from 24 to $33^{\circ} \mathrm{C}$ for experiment 2 .

Quantifying treatment effects and statistical analyses. The response variables "plant growth and fresh weight," "wilt development over time," "root area and discoloration," and "pathogen colonization" were evaluated following the same procedures detailed above. For each reduced SM study (15 and 10\% VWC), experiment and block were random variables, and both developmental-stage and pathogen treatments were fixed variables. There were no significant experiment $\times$ treatment interactions and no significant developmental stage $\times$ pathogen treatment interactions, and therefore, all data were pooled and analyzed together. Root area, root and shoot weight, AUSPC, percentage root discoloration, root infection incidence, and extent of colonization were analyzed as above. Plant was treated as the unit of replication (16 replicates per experiment; 32 for the two experiments

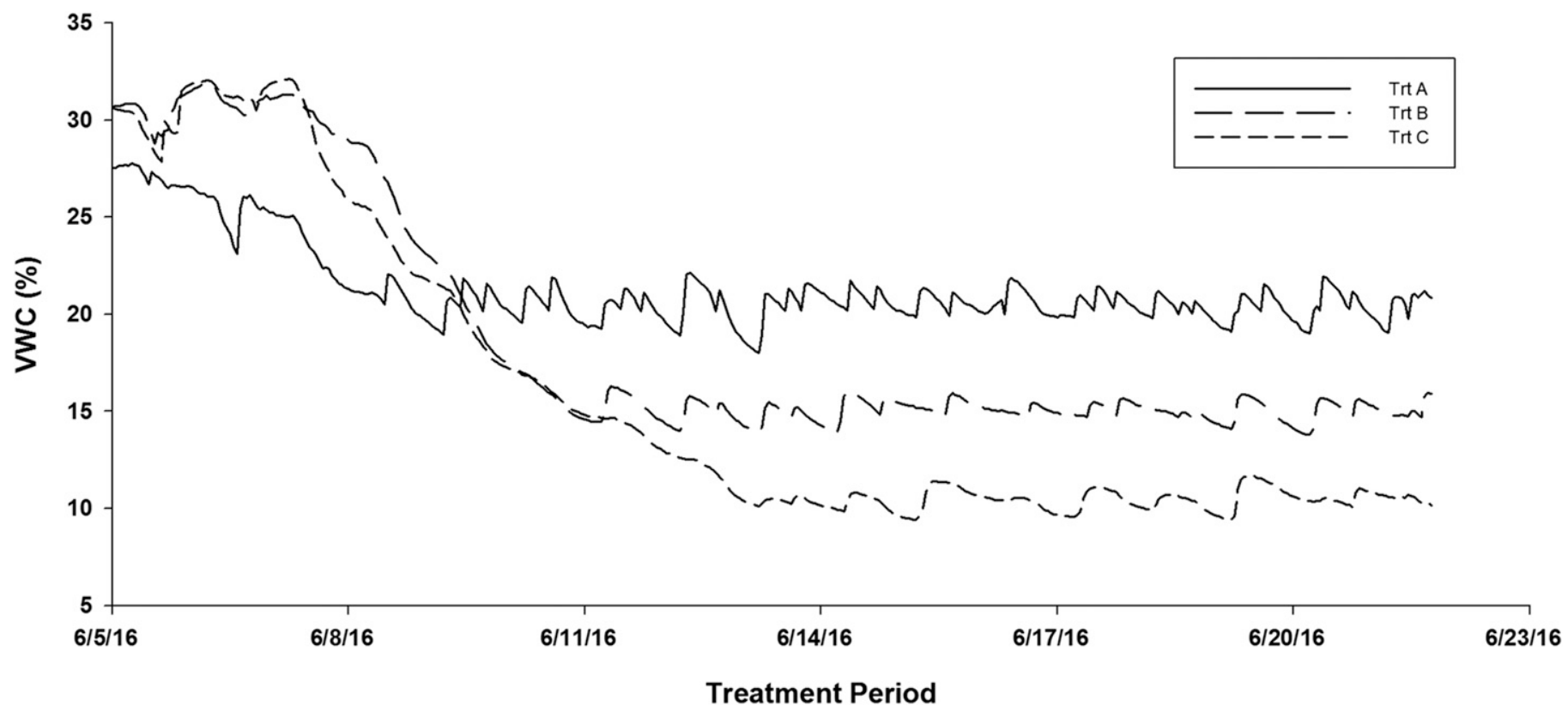

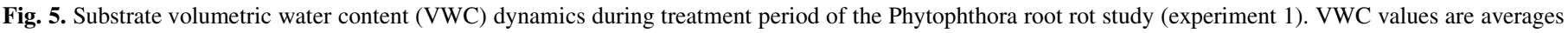
of five EC5 sensors per treatment. Treatment (Trt) A, 20\% VWC; Trt B, 15\% VWC; Trt C, 10\% VWC. 
combined) for all analyses except root infection incidence, in which block was treated as the unit of replication (4 replicates per experiment; 8 for experiments combined).

\section{RESULTS}

Effect of reduced SM levels on Phytophthora root and crown rot. Irrigation control and water application volumes. After the SM treatments were imposed, the VWC set points for the 20,15 , and $10 \%$ VWC treatments were kept within a narrow range by triggering irrigation events whenever the threshold substrate VWC for each particular treatment was reached. An example of the substrate VWC dynamics during the treatment period for experiment 1 is given in Figure 5. Irrigation events were triggered with the highest frequency for the $20 \%$ VWC treatment and decreased at the 15 and $10 \%$ VWC as indicated by the maximum and minimum VWC values (Fig. 5). The average irrigation water application volume for the two experiments in each study is given in Table 1. On average, irrigation application (liters per plant per day) to the mid- and low-range SM treatments were 16.8 and $44.1 \%$, respectively, lower than the $20 \%$ VWC for both experiments combined.

Shoot growth. Based on the $\mathrm{SM} \times$ pathogen treatment interaction, there was no effect of SM on shoot weight $(P=0.497)$ or plant height $(P=0.723)$ in either inoculated or noninoculated plants (Table 2$)$.
Root growth. SM had a significant effect on root area $(P=0.028)$, reflecting reduced root area under the lowest SM treatment $(10 \%$ VWC) compared with the higher moisture treatments (20 and 15\% VWC) in both inoculated and noninoculated plants. There was a significant difference between inoculated and noninoculated plants $(P<0.001)$, reflecting significantly lower root area in the pathogentreated plants at both 20 and $10 \%$ VWC. Taken together, the combination of the pathogen with SM reductions to $10 \%$ VWC significantly reduced root area compared with pathogen-treated plants at 20 and $15 \%$ VWC and noninoculated plants at $10 \%$ VWC. This indicates that negative effects of lower SM on root area reduction are enhanced by the presence of the pathogen. Similarly, root weight was significantly reduced under $10 \% \mathrm{VWC}(P<0.001)$, but the effects were the same in inoculated and noninoculated plants $(P=0.971)$, indicating that effects of reduced SM on root weight do no change in a pathogen background (Table 2).

Leaf water potential. There was a significant effect of SM treatment on leaf water potential $\left(\Psi_{\mathrm{w}} ; P=0.028\right)$, reflecting lower water potential at $10 \%$ VWC compared with higher SM treatments but only in inoculated plants (Table 2). Pathogen-treated plants had lower water potential than noninoculated plants $(P<0.001)$ but only under $10 \%$ VWC. Taken together, the combination of the pathogen with SM reductions to $10 \%$ VWC significantly reduced water potential compared with both pathogen-treated plants that were under 20 and $15 \%$ VWC as well as noninoculated plants at $10 \%$

TABLE 1. Total irrigation application volume and water use (in liters per plant, liters per plant per day, and cubic meters per hectare per day) for the effect of reduced substrate moisture on Phytophthora root rot and plant developmental-stage studies of tomato inoculated with Phytophthora capsici and irrigated under three substrate moisture treatments

\begin{tabular}{|c|c|c|c|c|c|c|c|c|}
\hline \multirow[b]{3}{*}{$\begin{array}{l}\text { Substrate moisture } \\
\text { treatment }\end{array}$} & \multicolumn{4}{|c|}{ Phytophthora root rot study } & \multicolumn{4}{|c|}{ Plant developmental-stage study } \\
\hline & \multirow[b]{2}{*}{$\begin{array}{l}\text { Irrigation application } \\
\text { (liters) }\end{array}$} & \multicolumn{3}{|c|}{ Irrigation water application } & \multirow[b]{2}{*}{$\begin{array}{l}\text { Irrigation application } \\
\text { (liters) }\end{array}$} & \multicolumn{3}{|c|}{ Irrigation water application } \\
\hline & & $\begin{array}{c}\text { Liters/ } \\
\text { plant }\end{array}$ & $\begin{array}{l}\text { Liters/plant/ } \\
\text { day }\end{array}$ & $\begin{array}{c}\mathrm{m}^{3} / \mathrm{ha} / \\
\text { day }\end{array}$ & & $\begin{array}{c}\text { Liters/ } \\
\text { plant }\end{array}$ & $\begin{array}{c}\text { Liters/plant/ } \\
\text { day }\end{array}$ & $\begin{array}{c}\mathrm{m}^{3} / \mathrm{ha} / \\
\text { day }\end{array}$ \\
\hline $20 \% \mathrm{VWC}^{\mathrm{y}}$ & 449 & 5.07 & 0.278 & 7.0 & $\mathrm{na}^{\mathrm{z}}$ & na & na & na \\
\hline $15 \%$ VWC & 382 & 4.13 & 0.232 & 5.8 & 422 & 3.96 & 0.263 & 6.6 \\
\hline $10 \%$ VWC & 263 & 2.71 & 0.156 & 3.9 & 377 & 3.56 & 0.237 & 5.9 \\
\hline
\end{tabular}

y VWC, volumetric water content.

$\mathrm{z}$ na: treatment not applied.

TABLE 2. Means of root area, root weight, shoot weight, leaf water potential $\left(\Psi_{\mathrm{w}}\right)$, plant height, area under the symptoms progress curve (AUSPC) values, decline incidence, and root discoloration percentage of tomato inoculated with Phytophthora capsici or noninoculated under different substrate moisture contents

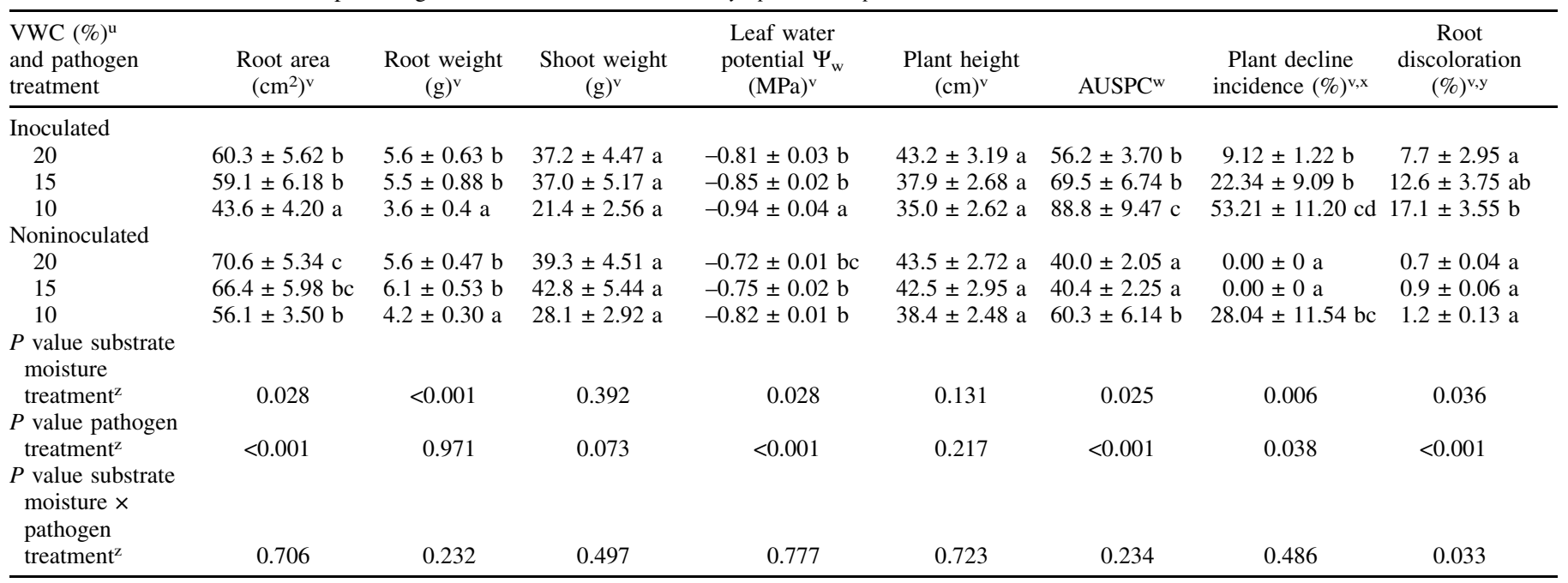

u Substrate moisture treatments consisted of 20,15 , and $10 \%$ volumetric water content (VWC).

v Values in a column followed by the same letter are not significantly different according to least square means significant difference $(P<0.05)$. The \pm is the standard error of the mean. Variables were analyzed using a proc mixed procedure with SAS 9.4 (SAS Institute Inc.).

${ }^{w}$ Mean ranks were estimated using the proc rank procedure and the analysis of variance test. Analyses were performed with proc mixed SAS 9.4 .

${ }^{x}$ Plant decline incidence at 28 days postinoculation defined as pronounced wilting (rating of $\geq 3$ ) (Fig. 5).

y The percentage of the root system discolored calculated using Assess 2.0 (Lamari 2008) following a scale from 31 to 101 color hue.

${ }^{\mathrm{z}}$ Based on least square means significant difference $P=0.05$. 
VWC. This indicates that effects of reduced SM in lowering water potential are enhanced by the presence of the pathogen.

Wilt development and severity. The first indicator of wilt development in inoculated plants was minor loss of turgor in the leaves (rating of 2), which began at $7 \mathrm{dpi}$; plants began to exhibit pronounced wilting (obvious loss of turgor; rating of 3 to 4 ) starting at $14 \mathrm{dpi}$, and mortality was first observed at $21 \mathrm{dpi}$. The rate of symptom development, measured by AUSPC, was greater at $10 \%$ VWC in both inoculated and noninoculated plants $(P=0.025)$ (Table 2). Rate of symptom development was greater in inoculated compared with noninoculated plants at all SM levels $(P<0.001)$. Thus, the combination of the pathogen with SM reductions to $10 \%$ VWC significantly increased the rate of symptom development compared with both pathogen-treated plants at 20 and $15 \%$ VWC as well as noninoculated plants at $10 \%$ VWC. This indicates that effects of reduced SM on increased rate of symptom development are enhanced by the presence of the pathogen.

At the final rating ( $28 \mathrm{dpi}$ ), wilt severity was significantly greater in inoculated plants in both the reduced SM treatments (15 and 10\% VWC) but not in well-watered plants (Fig. 6A). Within the inoculated plants, there was a significant effect of SM treatment on wilt severity $(P=0.0481)$ (Fig. 6A), wherein wilt severity under $10 \%$ VWC was $40 \%$ greater than at $20 \%$ VWC. The percentage of plants with advanced wilt symptoms (rating of 3 or greater) was also significantly affected by SM treatment $(P=0.006)$ and pathogen treatment $(P=0.038)$, wherein inoculated plants under 10\% VWC had the highest incidence of advanced wilting (53\% of plants) compared with plants under 20 and 15\% VWC (10 and 22\% of plants, respectively). Wilt symptoms (rating of 2 to 3 ) also developed in the absence of the pathogen but only in the $10 \%$ VWC treatment (effect of SM in noninoculated plants: $P=0.004$ ). Advanced wilt only developed in the $10 \%$ VWC treatment $(28 \%$ of plants) (Table 2), and no noninoculated plants suffered severe wilt or mortality (rating of 4 to 5). Thus, combining the pathogen with SM reductions to $10 \%$ VWC significantly increased wilt symptom compared with both pathogen-treated plants at 20 and $15 \%$ VWC as well as noninoculated plants at $10 \%$ VWC. This indicates that effects of reduced SM on increased symptom severity are enhanced by the presence of the pathogen.

Root system discoloration. There was a significant effect of SM on root system discoloration (rot; $P=0.036$ ), reflecting more severe root discoloration at $10 \%$ VWC compared with the two higher SM treatments (20 and 15\% VWC) only in inoculated plants. No root system discoloration developed in noninoculated plants $(P<0.001$ for pathogen treatment effect). Thus, the presence of the pathogen significantly increased the effect of SM reductions on root rot severity compared with both pathogen-treated plants that were well watered and noninoculated plants at the low-SM treatment. This indicates that effects of reduced SM on increased root rot severity are enhanced by the presence of the pathogen.

Pathogen colonization. P. capsici was recovered from inoculated plants in all of the irrigation treatments $(n=23)$ and was not recovered from any noninoculated plants $(n=96)$. All of the isolates recovered were confirmed as $P$. capsici by the amplification of the ITS region. Amplification products of $450 \mathrm{bp}$ were obtained using the set of species-specific primers (CAPFW and CAPRV1; $n=16$ ). The reverse primer CAPRV2 was used to amplify a product of 590 bp for a subset of isolates $(n=7)$ when the reverse primer CAPRV1 did not amplify. Irrigation treatment did not affect plant colonization incidence $(P=0.645)$; however, there was a trend in which the percentages of infected plants under 20 and $15 \%$ VWC treatments were 36 and $46 \%$ greater, respectively, than plants under the $10 \%$ VWC. In conditional analysis, the extent of root system colonization (percentage of $10[1-\mathrm{cm}]$ root segments colonized) in infected plants was uniform $(28 \pm 0.01 \%)$ across the three irrigation treatments $(P=0.980)$ (Table 3$)$.

Pathogen recovery was also evaluated separately for symptomatic plants (with root rot and/or crown rot) and asymptomatic plants

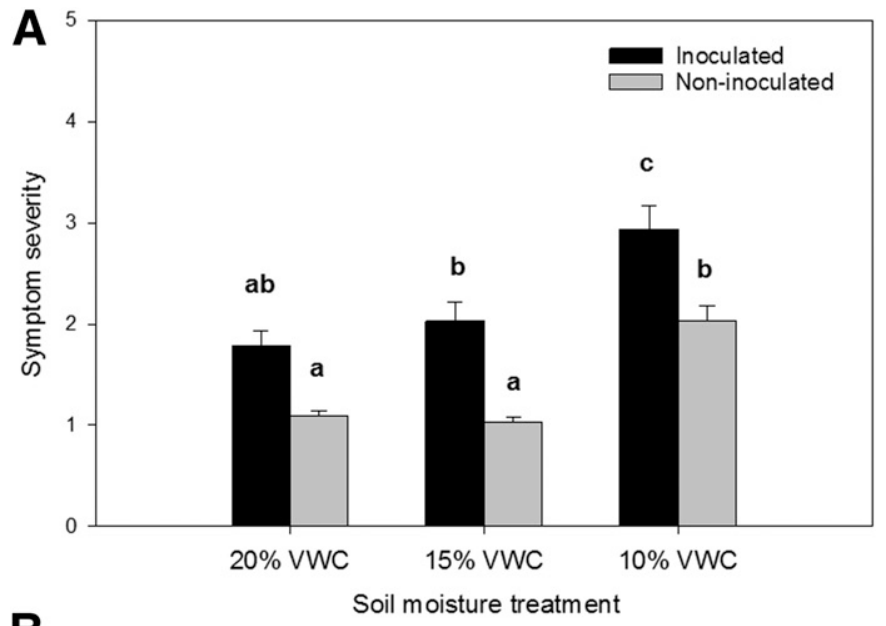

B
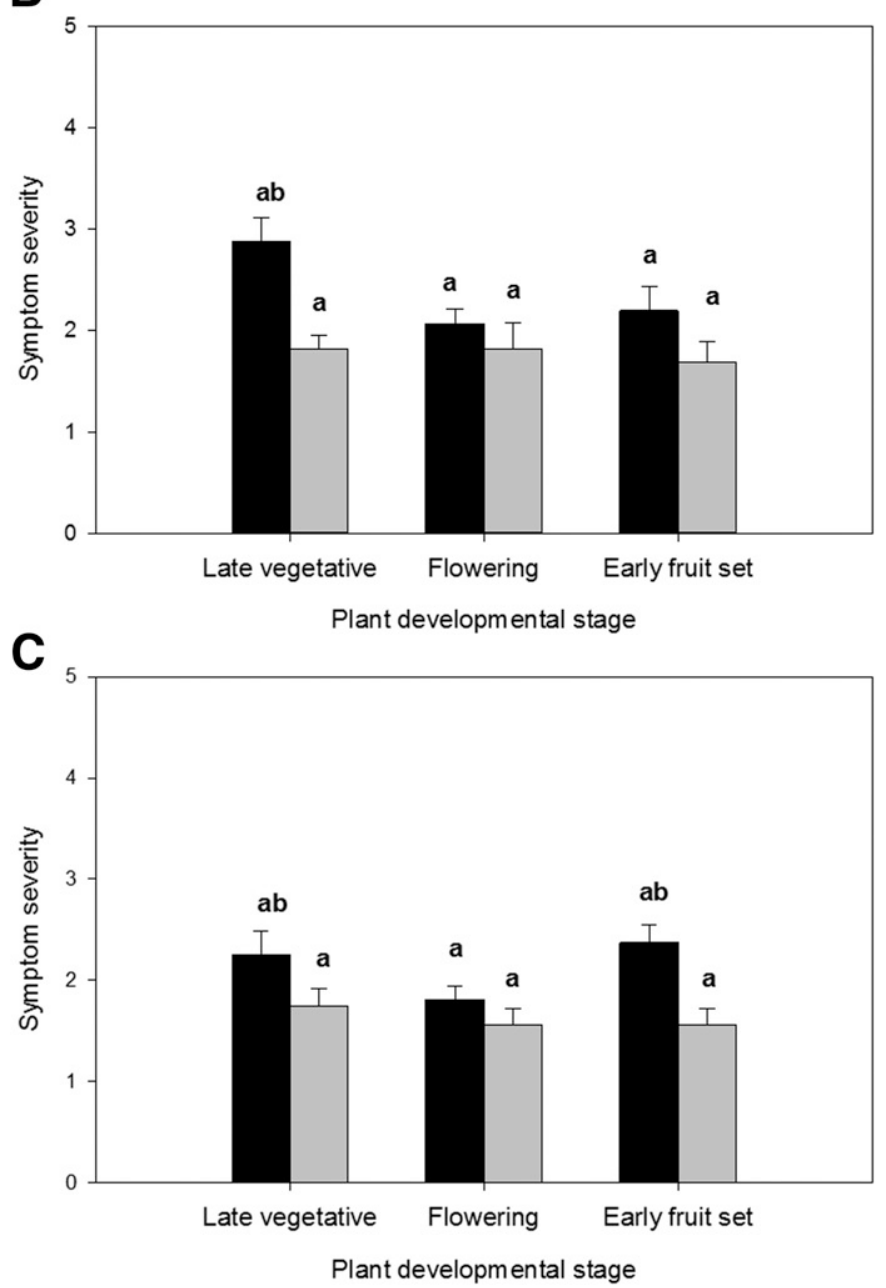

Fig. 6. Wilt severity caused by Phytophthora capsici and abiotic factors at 28 days postinoculation on tomato subjected to three substrate moisture contents: well-watered ( $20 \%$ volumetric water content [VWC]), midrange (15\% VWC), and low-range (10\% VWC) substrate moisture. Symptom severity was rated from 7 to 28 days postinoculation on a 1 to 5 scale, where $1=$ no symptoms, 2 $=1$ to $30 \%$ of the plant wilted (minor wilting of the leave tips), $3=31$ to $50 \%$ of the plant wilted (leaves wilting is more pronounce), $4=51$ to $80 \%$ of the plant wilted (major wilting of leaves), and $5=>80 \%$ of the plant wilted or plant death (Quesada-Ocampo and Hausbeck 2010). A, Effect of reduced substrate moisture on wilt severity in Phytophthora root rot study $(P=0.048)$. B, Effect of midrange substrate moisture (15\% VWC) on wilt severity when imposed at different plant developmental stages (late vegetative, flowering, and early fruit set; $P=0.200)$. C, Effect of low-range substrate moisture (10\% VWC) on wilt severity when imposed at different plant developmental stages (late vegetative, flowering, and early fruit set; $P=0.206$ ). Bars represent the mean average of rating values, error bars represent the standard error of the mean, and bars with the same letter are not significantly different. 
(no symptoms in root and crown tissue). $P$. capsici was recovered from roots of 10 to $17 \%$ of symptomatic plants across all SM treatments, with no effect of SM treatment $(P=0.307)$. The pathogen was recovered from roots of only 1.6 to $6.2 \%$ of asymptomatic plants (Table 3). Despite low incidence, the extent of asymptomatic root colonization in the $10 \%$ VWC treatment was significantly higher than in the 15 and $20 \%$ VWC treatments (41 and $83 \%$, respectively) (Table 3 ).

Effect of plant developmental stage on SM-pathogen interactions: Midrange SM (15\% VWC). Plant growth. In analyses of root area and root weight, there was no significant effect of either the plant developmental stage at which midrange SM was initiated $(P=0.173$ and 0.064 , respectively) or the pathogen treatment ( $P=0.965$ and 0.727 , respectively) (Table 4). However, there was a trend in which root size was lower when $15 \%$ VWC was initiated at early fruit set (16-week-old) compared with flowering (14-week-old) and late vegetative (12-week-old) stages in both inoculated and noninoculated plants. Developmental stage had a significant effect on shoot weight $(P=0.023)$, which was reduced by one-half at early fruit set ( 16 weeks old) compared with initiation at the late vegetative stage (12 weeks old) for inoculated plants (Table 4). There was no effect of developmental stage in noninoculated plants (Table 4), indicating that the presence of the pathogen significantly altered the importance of applying reduced SM at different developmental stages such that shorter applications starting when plants were older (at fruit set) reduced shoot growth more than longer applications starting when plants were younger (at a late vegetative stage).

Wilt development. Minor wilting of foliage was first observed at 7 dpi, but symptoms did not progress significantly over time. There was no effect of developmental stage on wilt severity in which 30 to $50 \%$ of plants developed wilt symptoms across all treatments $(P=$ 0.200 ) (Fig. 6B). The average wilt rating at the end of the experiment was 2.4 for inoculated plants across all developmental stages (Fig. 6B). Similarly, variations in the AUSPC values did not differ across developmental stages $(P=0.627)$, although comparing inoculated and noninoculated plants, AUSPC values were consistently greater in inoculated plants; this difference was most notable in plants treated at the youngest developmental stage, wherein AUSPC was $40 \%$ greater in inoculated compared with noninoculated plants.

Root rot development. Root discoloration was significantly greater in inoculated plants $(P<0.001)$. There was significant means segregation across developmental stages within the inoculated plants, wherein root system discoloration was significantly greater when $15 \%$ VWC was initiated at the late vegetative stage (12 weeks old) compared with implementation at early fruit set (16 weeks old) (Table 4). There was no effect of plant developmental stage on root rot in noninoculated plants. Thus, based on root rot development, the presence of the pathogen significantly altered the

TABLE 3. Root infection incidence and extent of colonization in tomatoes inoculated with Phytophthora capsici under three substrate moisture treatments

\begin{tabular}{|c|c|c|c|c|c|c|}
\hline \multirow[b]{2}{*}{ VWC $(\%)^{\mathrm{v}}$} & \multicolumn{2}{|c|}{ Total plants ${ }^{\mathrm{w}}$} & \multicolumn{2}{|c|}{ Symptomatic plants ${ }^{\mathrm{w}}$} & \multicolumn{2}{|c|}{ Asymptomatic plantsw } \\
\hline & $\begin{array}{l}\text { Infection incidence } \\
\qquad(\%)^{\mathrm{x}}\end{array}$ & $\begin{array}{l}\text { Extent of colonization } \\
(\%)^{\mathrm{y}}\end{array}$ & $\begin{array}{l}\text { Infection incidence } \\
(\%)^{\mathrm{x}}\end{array}$ & $\begin{array}{l}\text { Extent of colonization } \\
(\%)^{\mathrm{y}}\end{array}$ & $\begin{array}{l}\text { Infection incidence } \\
(\%)^{\mathrm{x}}\end{array}$ & $\begin{array}{c}\text { Extent of colonization } \\
\qquad(\%)^{\mathrm{y}}\end{array}$ \\
\hline 20 & $17.2 \pm 7.10 \mathrm{a}$ & $30.0 \pm 10.01 \mathrm{a}$ & $11.0 \pm 6.07 \mathrm{a}$ & $37.0 \pm 12.00 \mathrm{a}$ & $6.2 \pm 4.00 \mathrm{a}$ & $10.0 \pm 0.00 \mathrm{a}$ \\
\hline 15 & $20.3 \pm 8.04 \mathrm{a}$ & $26.6 \pm 7.02 \mathrm{a}$ & $17.2 \pm 8.10 \mathrm{a}$ & $20.0 \pm 4.40 \mathrm{a}$ & $6.2 \pm 3.03 \mathrm{a}$ & $35.0 \pm 15.00 \mathrm{ab}$ \\
\hline 10 & $10.9 \pm 3.20 \mathrm{a}$ & $28.3 \pm 8.24 \mathrm{a}$ & $10.0 \pm 3.01 \mathrm{a}$ & $22.0 \pm 7.35 \mathrm{a}$ & $1.6 \pm 0.00 \mathrm{a}$ & $60.0 \pm 0.00 \mathrm{~b}$ \\
\hline $\begin{array}{c}P \text { value sub } \\
\text { moisture } \\
\text { treatment }^{\mathrm{z}}\end{array}$ & 0.645 & 0.980 & 0.604 & 0.307 & 0.515 & 0.238 \\
\hline
\end{tabular}

v Substrate moisture treatments consisted of 20,15 , and $10 \%$ volumetric water content (VWC).

${ }^{\mathrm{w}}$ Mean root infection incidence and extent of colonization in a column followed by the same letter are not significantly different according to least square means significant difference $(P<0.05)$. The \pm is the standard error of the mean. Variables were analyzed using a proc mixed procedure with SAS 9.4 (SAS Institute Inc.).

${ }^{x}$ Root infection incidence was quantified as the percentage of inoculated plants from which $P$. capsici was recovered from one or more root segments.

y The extent of root colonization was analyzed conditionally based on the percentage of $1-\mathrm{cm}$ root segments (/10) from which $P$. capsici was recovered only in those plants that were infected.

$\mathrm{z}$ Based on least square means significant difference $P=0.05$.

TABLE 4. Root area, root weight, shoot weight, area under the symptoms progress curve (AUSPC), and root discoloration percentage of tomato plants irrigated under midrange substrate moisture (15\% volumetric water content) at different developmental stages/durations and then inoculated with Phytophthora capsici or not inoculated

\begin{tabular}{|c|c|c|c|c|c|c|}
\hline $\begin{array}{l}\text { Pathogen and plant } \\
\text { developmental stage }\end{array}$ & $\begin{array}{c}\text { Irrigation } \\
\text { duration } \\
(\text { weeks) }\end{array}$ & Root area $\left(\mathrm{cm}^{2}\right)^{\mathrm{w}}$ & Root weight $(\mathrm{g})^{\mathrm{w}}$ & Shoot weight $(\mathrm{g})^{\mathrm{w}}$ & AUSPC $^{x}$ & Root discoloration $(\%)^{\mathrm{w}, \mathrm{y}}$ \\
\hline \multicolumn{7}{|l|}{ Inoculated } \\
\hline Flowering & 4 & $95.0 \pm 6.36 \mathrm{a}$ & $9.3 \pm 0.83 \mathrm{ab}$ & $93.1 \pm 10.36 \mathrm{ab}$ & $69.1 \pm 7.63 \mathrm{a}$ & $3.4 \pm 0.53 \mathrm{bc}$ \\
\hline Early fruit set & 2 & $79.4 \pm 7.4 \mathrm{a}$ & $7.4 \pm 0.73 \mathrm{a}$ & $70.7 \pm 6.75 \mathrm{a}$ & $68.0 \pm 5.44 \mathrm{a}$ & $3.0 \pm 0.54 \mathrm{~b}$ \\
\hline \multicolumn{7}{|l|}{ Noninoculated } \\
\hline Late vegetative stage & 6 & $103.6 \pm 6.39 \mathrm{a}$ & $12.1 \pm 1.62 \mathrm{ab}$ & $110.5 \pm 14.44 \mathrm{ab}$ & $56.2 \pm 5.03 \mathrm{a}$ & $0.72 \pm 0.09 \mathrm{a}$ \\
\hline$P$ value developmental-stage treatment ${ }^{z}$ & & 0.173 & 0.064 & 0.023 & 0.627 & 0.342 \\
\hline$P$ value pathogen treatment ${ }^{\mathrm{z}}$ & & 0.965 & 0.727 & 0.512 & 0.037 & $<0.001$ \\
\hline
\end{tabular}


importance of applying reduced SM application at different developmental stages, in which longer application duration starting when plants were younger (at late vegetative stage) increased the extent of root rot compared with shorter application duration starting when plants were at fruit set.

Pathogen colonization. P. capsici was recovered from all plants with root rot symptoms. The developmental stage at which $15 \%$ VWC was initiated had no significant effect on the incidence of plants colonized based on ANOVA $(P=0.075)$ (Table 5). However, LSD (a less conservative test) indicated significant differences in means separations, in which incidence of plant colonization was significantly $(75 \%)$ greater in plants irrigated at $15 \%$ VWC starting at early fruit set (16 weeks old) compared with younger plants irrigated at $15 \%$ VWC starting at the late vegetative stage (12 weeks old). The stage of plant development did not have a significant effect on the extent of root colonization based on either ANOVA $(P=$ 0.459 ) or LSD, although there was a trend in which the extent of $P$. capsici root colonization was lower in plants treated with $15 \%$ VWC starting at the late vegetative stage than at the other development stages (Table 5).

Effect of plant developmental stage on SM-pathogen interactions: Low-range SM $(\mathbf{1 0 \%}$ VWC). Plant growth. There was no effect of pathogen treatment on shoot $(P=0.328)$ or root weight $(P=0.467)$, and the root and shoot weights at each developmental stage were similar regardless of pathogen treatment (Table 6). The developmental stage at which $10 \%$ VWC was initiated had a significant effect on root weight $(P=0.023)$ and shoot weight $(P=0.032)$; when the low-range SM treatment was initiated at early fruit set, root and shoot weights were both onehalf that of the plants at late vegetative stage for both inoculated and noninoculated plants. There was no effect of either treatment on total root area.

Wilt and root rot development. Minor wilting of the leaves was first observed at $7 \mathrm{dpi}$, but symptoms did not progress significantly over time, resulting in a low average disease rating (average of 2.2) at the end of the experiment (Fig. 6C). Wilt severity was similar when $10 \%$ VWC was initiated at the different developmental stages $(P=0.206)$ (Fig. 6C). There was significant variation in AUSPC values for pathogen treatment $(P=0.006)$ but not plant developmental stage $(P=0.398)$ (Table 6); within inoculated plants, AUSPC did not vary significantly by developmental stage. Similarly, root discoloration was significantly greater in the inoculated compared with noninoculated plants for all developmental stages $(P<0.001)$. Similar to the $15 \%$ VWC study, root discoloration in inoculated plants was greater when low-range $10 \%$ VWC was applied at the youngest developmental stage, but differences were not significant.

Pathogen colonization. The patterns of pathogen colonization were similar to those in the $15 \%$ VWC study. Based on ANOVA, there was no significant difference in the incidence of pathogen colonization across plant developmental stages $(P=$ 0.090). However, LSD analysis indicated that infection incidence was greater when $10 \% \mathrm{VWC}$ was applied starting at early fruit set than at flowering (Table 5). In this study, the pathogen was not recovered from any plants in the late vegetative treatment. Plant developmental stage did not have a significant effect on the extent of root colonization $(P=0.177)$ (Table 5).

\section{DISCUSSION}

Within the nursery and greenhouse industry, there is increasing interest in reducing irrigation rates using sensor control systems to adapt to constraints in water availability for containerized and noncontainerized production. However, adoption of irrigation practices that reduce water inputs is hindered by concerns that water stress will increase losses from common nursery pathogens, particularly oomycetes, which can be more aggressive in waterstressed plants (DiLeo et al. 2010; Ristaino and Duniway 1989; Ristaino et al. 1991). Because most (if not all) irrigation management research focuses on direct physiological effects on crop productivity and does not consider biotic risks, there are currently no resources that producers can turn to for information on irrigation strategies that mitigate disease risks. Overall, our results suggest that irrigation regimes that reduce SM can significantly alter Phytophthora root disease dynamics in containerized tomato plants, but disease risks can be mitigated to achieve water use reductions. Although there have been many studies to evaluate drought-mediated plant-pathogen interactions, this is one of the first to translate these interactions to water scarcity adaptation scenarios and provide information relevant to irrigation management under pathogen pressure.

In this study, low-range SM reductions (10\% VWC) increased root rot and wilt severity under pathogen pressure based on increases in root rot severity, negative water potential, rate of symptom progress, and canopy symptom severity compared with both pathogen-treated plants that were well watered (20\% VWC) as well as noninoculated plants at $10 \%$ VWC. In the absence of the pathogen, low-range moisture reductions had no significant effects on water potential or root rot severity compared with well-watered plants, indicating that, based on these response variables, introduction of the pathogen shifted the $10 \%$ VWC treatment from a no-risk to a high-risk scenario. Root area reductions and increased rate of symptom development were also significantly enhanced under the noninoculated low-range moisture treatment compared with well-watered plants, but these effects were more severe in the presence of $P$. capsici. Based on these metrics, pathogen presence shifted the $10 \%$ VWC treatment from a low-risk to a high-risk scenario. Taken together, these results indicate that reduced irrigation

TABLE 5. Root infection incidence (percentage) and extent of colonization (percentage) for tomato plants irrigated under mid- and low-substrate moisture (15 or $10 \%$ volumetric water content [VWC], respectively) at different developmental stages/durations and then inoculated with Phytophthora capsici

\begin{tabular}{|c|c|c|c|}
\hline $\begin{array}{l}\text { VWC }(\%)^{\mathrm{u}} \text { and plant } \\
\text { developmental stage }\end{array}$ & $\begin{array}{l}\text { Irrigation } \\
\text { duration } \\
(\text { weeks) }\end{array}$ & $\begin{array}{l}\text { Infection } \\
\text { incidence } \\
(\%)^{\mathrm{w}, \mathrm{x}}\end{array}$ & $\begin{array}{l}\text { Extent of } \\
\text { colonization } \\
(\%)^{\mathrm{w}, \mathrm{y}}\end{array}$ \\
\hline \multicolumn{4}{|l|}{15} \\
\hline Late vegetative stage & 6 & $6.2 \pm 0.06 \mathrm{a}$ & $10.0 \pm 0.00 \mathrm{a}$ \\
\hline Flowering & 4 & $18.7 \pm 6.06 \mathrm{ab}$ & $23 \pm 13.10 \mathrm{a}$ \\
\hline Early fruit set & 2 & $25.0 \pm 0.00 \mathrm{~b}$ & $37.5 \pm 9.04 \mathrm{a}$ \\
\hline \multicolumn{4}{|l|}{10} \\
\hline Flowering & 6 & $12.5 \pm 7.01 \mathrm{AB}$ & $15.0 \pm 5.02 \mathrm{AB}$ \\
\hline Early fruit set & 4 & $25.0 \pm 10.00 \mathrm{~B}$ & $10.0 \pm 0.00 \mathrm{~A}$ \\
\hline $\begin{array}{l}P \text { value among plant } \\
\text { developmental stages } \\
(15 \% \text { VWC })^{\mathrm{z}}\end{array}$ & & 0.075 & 0.459 \\
\hline $\begin{array}{l}P \text { value among plant } \\
\text { developmental stages } \\
(10 \% \mathrm{VWC})^{\mathrm{z}}\end{array}$ & & 0.090 & 0.177 \\
\hline
\end{tabular}

u Substrate moisture treatments consisted of 15 and $10 \%$ of VWC.

$\mathrm{v}$ Tomatoes at late vegetative, flowering, and early fruit set stages were irrigated during 6, 4, and 2 weeks, respectively, and then inoculated with P. capsici.

${ }^{\text {w }}$ Mean values of root infection incidence and the extent of colonization in a column followed by the same letter are not significantly different according to least square means significant difference $(P<0.05)$. Analyses were conducted for 15 and $10 \%$ VWC studies separately, in which lowercase letters denote differences under $15 \%$ VWC and uppercase letters denote differences at $10 \%$ VWC. The \pm is the standard error of the mean. Variables were analyzed using a proc mixed procedure with SAS 9.4 (SAS Institute Inc.).

$x$ Root infection incidence was estimated as the percentage of inoculated plants from which P. capsici was recovered from one or more root segments. $y$ The extent of root colonization was analyzed conditionally based on the percentage of $1-\mathrm{cm}$ root segments (/10) from which $P$. capsici recovered only in those plants that were infected.

${ }^{\mathrm{z}}$ Based on least square means significant difference $P=0.05$. 
strategies that may otherwise seem to have minor to no impact to plant productivity based on physiological measures alone can be significantly damaging under pathogen pressure. Thus, plant pathogens seem to increase the risks associated with reduced irrigation inputs. This study also suggests that a range of response variables should be considered in assessing biotic risks of water use reductions, because they will give different assessments of risk.

These results support the hypothesis that exposure to very low SM levels may predispose plants to root rot. There are various studies showing that water stress can reduce host resistance to oomycete pathogens and defining the parameters under which predisposition occurs. Ristaino and Duniway (1989) found that the severity of $P$. parasitica damping off was higher in water-stressed tomato seedlings than in nonstressed plants (Ristaino and Duniway 1989). Similarly, in a study by DiLeo et al. (2010), wilt incidence and severity in tomatoes infected by $P$. capsici were greater under salinity-induced predisposition (DiLeo et al. 2010). Bostock et al. (2014) found that exposing plants to water potential deficits in the range from -0.5 to $-1 \mathrm{MPa}$ correlated with predisposition to Phytophthora disease in tomato (Bostock et al. 2014). In our experiments, water potential levels reached $-0.82 \mathrm{MPa}$ in noninoculated plants under the low-range SM treatment (10\% VWC)low enough to predispose plants to disease. These results suggest that predisposition analysis should be included in water use risk assessment to avoid irrigation treatments that increase disease susceptibility.

The implementation of a midrange reduced SM status $(15 \%$ VWC) did not increase root rot severity, and it did not affect plant growth (plant height, shoot weight, root area, and root weight) or water conductance (based on leaf water potential). Use of midrange SM (15\% VWC) resulted in a $16.8 \%$ reduction in irrigation water inputs compared with the well-watered treatment (20\% VWC). If implemented in a commercial greenhouse tomato production with a standard planting density of 25,000 plants per 1 ha, this would translate to a water savings of $\sim 35 \mathrm{~m}^{3}$ (35,000 liters) of water per hectare per month. However, this is a conservative estimate, because water savings are likely to be significantly higher in production conditions depending on the efficiency of the irrigation system implemented (for example, drip or sprinkler irrigation). These results indicate that it is possible to save water without increasing disease risk by modulating the severity of water use reduction.

Tomato was used as a reference system: it is grown commercially in containers as field and garden transplants and also, to maturity for greenhouse-grown fruit. The increase in disease development under reduced SM has economic implications on transplant and mature plant losses (DiLeo et al. 2010; Hausbeck and Lamour 2004; Quesada-Ocampo and Hausbeck 2010; Ristaino and Duniway 1989). Although we did not evaluate fruit production because of restrictions in availability of the sensor network irrigation system, $P$. capsici also is known to cause losses in fresh market and processing tomato yields (Hausbeck and Lamour 2004; Ristaino and Duniway 1989; Ristaino et al. 1991), indicating that reductions in SM that enhance disease development could also impact fruit production.

Reducing SM also increased the extent of asymptomatic (or cryptic) root infection. Asymptomatically infected nursery plants are some of the primary means by which pathogens are moved across county, state, and country borders. For example, infection of healthy-looking nursery stock by $P$. ramorum has received intense regulatory scrutiny, because this pathogen has been repeatedly introduced into forests and urban landscapes on nursery stock, where it has caused significant losses of native tree species, such as tan oak (Notholithocarpus densilorus), as well as important landscape trees and shrubs (Rizzo et al. 2005). Results from our study suggest the possibility that reducing SM could also increase the frequency of cryptic pathogen infection and subsequent introduction of pathogens into new regions.

Not surprisingly, lower SM also affected growth of noninoculated plants. In our study, root weight and root area of noninoculated plants were significantly reduced under the $10 \%$ VWC treatment. Similarly, Obreza et al. (1996) found that, at the end of the tomato crop production, plant size and canopy density decreased at lower soil moisture contents (Obreza et al. 1996). It has also been shown that reduced irrigation implemented in ornamental containerized production systems reduced plant size (Cameron et al. 2008; Davies et al. 2016). It is possible that these effects would not result in detectable yield reductions for the producer.

Our results suggest that strategically reducing SM at certain developmental stages or certain durations can also be significant to disease risk. Although midrange soil moisture reductions $(15 \%$ VWC) initially seemed to have no effect on plant performance (the first study), when we compared applications initiated at different developmental stages and for varying durations, risk was altered. It is significant to note that effects of developmental stage cannot herein be differentiated from the length of time over which plants were under reduced irrigation; additional in-depth studies are needed for such differentiation. Regardless, because the pathogen treatment was applied after plants were returned to normal watering, alterations in host-pathogen interactions can be attributed

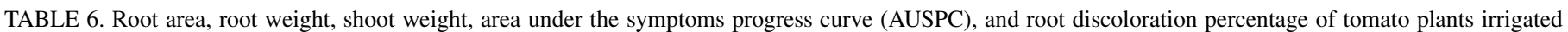

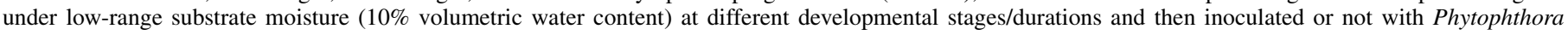
capsici

\begin{tabular}{|c|c|c|c|c|c|c|}
\hline Pathogen and plant developmental stage ${ }^{\mathrm{v}}$ & $\begin{array}{l}\text { Irrigation } \\
\text { duration } \\
(\text { weeks })^{\mathrm{v}}\end{array}$ & Root area $\left(\mathrm{cm}^{2}\right)^{\mathrm{w}}$ & Root weight $(\mathrm{g})^{\mathrm{w}}$ & Shoot weight $(\mathrm{g})^{\mathrm{w}}$ & AUSPC $^{x}$ & Root discoloration $(\%)^{\mathrm{w}, \mathrm{y}}$ \\
\hline \multicolumn{7}{|l|}{ Inoculated } \\
\hline Late vegetative stage & 6 & $92.6 \pm 13.1 \mathrm{a}$ & $13.1 \pm 2.35 b$ & $122.1 \pm 18.7 \mathrm{ab}$ & $79.2 \pm 13.36 \mathrm{ab}$ & $4.6 \pm 1.29 \mathrm{~b}$ \\
\hline Flowering & 4 & $83.0 \pm 8.3 \mathrm{a}$ & $8.3 \pm 1.1 \mathrm{a}$ & $93.2 \pm 12.26 \mathrm{ab}$ & $64.3 \pm 7.2 \mathrm{ab}$ & $3.7 \pm 0.59 b$ \\
\hline Early fruit set & 2 & $67.6 \pm 7.19 \mathrm{a}$ & $6.1 \pm 0.62 \mathrm{a}$ & $68.3 \pm 7.57 \mathrm{a}$ & $84.6 \pm 8.32 b$ & $3.8 \pm 0.63 b$ \\
\hline \multicolumn{7}{|l|}{ Noninoculated } \\
\hline Late vegetative stage & 6 & $107.2 \pm 8.01 \mathrm{a}$ & $13.6 \pm 2.47 \mathrm{~b}$ & $131.5 \pm 18.16 b$ & $52.9 \pm 3.92 \mathrm{a}$ & $0.7 \pm 0.11 \mathrm{a}$ \\
\hline Flowering & 4 & $89.9 \pm 6.13 \mathrm{a}$ & $8.9 \pm 1.12 \mathrm{ab}$ & $104.8 \pm 12.07 \mathrm{ab}$ & $55.6 \pm 5.35 \mathrm{a}$ & $0.6 \pm 0.08 \mathrm{a}$ \\
\hline Early fruit set & 2 & $80.2 \pm 5.47 \mathrm{a}$ & $6.9 \pm 0.49 \mathrm{a}$ & $74.5 \pm 6.02 \mathrm{a}$ & $54.0 \pm 2.14 \mathrm{a}$ & $0.8 \pm 0.11 \mathrm{a}$ \\
\hline$P$ value developmental-stage treatment $\mathrm{z}^{\mathrm{z}}$ & & 0.092 & 0.023 & 0.032 & 0.398 & 0.734 \\
\hline$P$ value pathogen treatment ${ }^{\mathrm{z}}$ & & 0.072 & 0.467 & 0.328 & 0.006 & $<0.001$ \\
\hline \multicolumn{7}{|c|}{$\begin{array}{l}\text { v Tomatoes at late vegetative, flowering, and early fruit set stages were irrigated during } 6,4 \text {, and } 2 \text { weeks, respectively, and then inoculated with } P \text {. capsici. } \\
\text { w Mean values in a column followed by the same letter are not significantly different according to least square means significant difference }(P<0.05) \text {. The } \pm \text { is th } \\
\text { standard error of the mean. Variables were analyzed using a proc mixed procedure with SAS } 9.4 \text { (SAS Institute Inc.). }\end{array}$} \\
\hline
\end{tabular}


solely to treatment effects on host resistance and not to direct effects on the pathogen.

The differential effects of treatment timing on plant development, pathogen infection, and disease were not consistent across response variables. Where $P$. capsici inoculated plants had lower shoot biomass and greater root infection incidence when $15 \%$ VWC was applied to older compared with younger plants, the inverse was true for root rot severity, with greater severity when $15 \%$ VWC was applied to younger plants. This effect was also seen in noninoculated plants, although irrigation treatment differences were not significant. Inconsistencies indicates the need for additional work. In accounting for effects on root rot, increased drought stress could have reduced host defenses to later pathogen infection (pathogen predisposition; discussed above), allowing more rapid root rot development. In physiological studies of both greenhousegrown (Chen et al. 2013) and field-grown tomatoes (Kuşçu et al. 2014), deficit irrigation initiated at flowering and fruit development resulted in reductions in fruit yield compared with when initiated at younger development (Chen et al. 2013; Kuşçu et al. 2014). Similarly, Nuruddin et al. (2003) found that, in greenhouse tomatoes, application of water stress at flowering resulted in greater fruit yields than applications later in the season (Nuruddin et al. 2003).

In all studies, pathogen recovery was low (often $<15 \%$ ). The reason for low pathogen recovery rates may be that, under dry conditions, it is harder to achieve zoospore release and dispersal. In these studies, P. capsici abundance was quantified as the number of colonies obtained from 10 root pieces per plant; to further evaluate the effects of SM stress on $P$. capsici infection, quantification of the pathogen colonization in a larger subset of the root system and quantification of pathogen load in the substrate would greatly enhance interpretation. Also, the sand substrate could influence P. capsici survival and growth. Duniway (1976) and Newhook et al. (1981) showed that sandy substrates can be antagonistic to persistence of Phytophthora species. For future studies, it would be important to consider the effect of different substrates in pathogen survival and plant health under reduced SM scenarios.

The implementation of set point-controlled reductions in SM provides a useful tool to reduce water usage in containerized production, but there is a threshold over which disease risk is increased. This study evaluated a single oomycete pathogen in a single host. Downstream studies are needed to determine whether the risks of SM reductions are consistent across other root rot pathogens, including additional oomycete species as well as true fungi. These studies may indicate a predisposition effect of reduced water use, but more studies are needed to characterize this dynamic and provide additional insight into traits of high- and low-risk pathosystems. Evaluating irrigation thresholds across an expanded suite of pathosystems will be critical to develop management strategies that allow producers to respond to water use restrictions without increasing disease losses in containerized nursery production. To facilitate adaptive water use management, both the severity of the SM reduction and the developmental stage of initial deployment were identified as factors that could be manipulated to mitigate oomycete disease risk while enabling water use reduction.

\section{ACKNOWLEDGMENTS}

We thank Beth Hellman, Emmi Koivunen, Nate Riley, and Elizabeth Prinkey for experimental assistance.

\section{LITERATURE CITED}

Bayer, A., Ruter, J., and Van Iersel, M. W. 2015. Automated irrigation control for improved growth and quality of Gardenia jasminoides 'Radicans' and 'August Beauty'. HortScience 50:78-84.

Belayneh, B. E., Lea-Cox, J. D., and Lichtenberg, E. 2013. Costs and benefits of implementing sensor-controlled irrigation in a commercial pot-in-pot container nursery. HortTechnology 23:760-769.
Bernhardt, E., and Grogan, R. 1982. Effect of soil matric potential on the formation and indirect germination of sporangia of Phytophthora parasitica, Phytophthora capsici, and Phytophthora cryptogea [Rots of tomatoes, Lycopersicon esculentum]. Phytopathology 72:507-511.

Bostock, R. M., Pye, M. F., and Roubtsova, T. V. 2014. Predisposition in plant disease: Exploiting the nexus in abiotic and biotic stress perception and response. Annu. Rev. Phytopathol. 52:517-549.

Bryla, D. R., and Linderman, R. G. 2007. Implications of irrigation method and amount of water application on Phytophthora and Pythium infection and severity of root rot in highbush blueberry. HortScience 42:1463-1467.

Buxton, G., Cyr, D., Dumbroff, E., and Webb, D. 1985. Physiological responses of three northern conifers to rapid and slow induction of moisture stress. Can. J. Bot. 63:1171-1176.

Cameron, R., Harrison-Murray, R., Fordham, M., Wilkinson, S., Davies, W., Atkinson, C., and Else, M. 2008. Regulated irrigation of woody ornamentals to improve plant quality and precondition against drought stress. Ann. Appl. Biol. 153:49-61.

Cameron, R., Harrison-Murray, R., and Scott, M. A. 1999. The use of controlled water stress to manipulate growth of container-grown Rhododendron cv. Hoppy. J. Hortic. Sci. Biotechnol. 74:161-169.

Chappell, M., Dove, S. K., Van Iersel, M. W., Thomas, P. A., and Ruter, J. 2013. Implementation of wireless sensor networks for irrigation control in three container nurseries. HortTechnology 23:747-753.

Chen, J., Kang, S., Du, T., Qiu, R., Guo, P., and Chen, R. 2013. Quantitative response of greenhouse tomato yield and quality to water deficit at different growth stages. Agric. Water Manage. 129:152-162.

Cobos, D. R., and Chambers, A. C. 2010. Calibrating ECH2O Soil Moisture Sensors. https://www.metergroup.com/environment/articles/how-calibratesoil-moisture-sensors/

Connor, R. 2015. The United Nations World Water Development Report 2015: Water for a Sustainable World. UNESCO Publishing, Paris, France.

Cook, R., and Papendick, R. 1972. Influence of water potential of soils and plants on root disease. Annu. Rev. Phytopathol. 10:349-374.

Costa, J. M., Ortuño, M. F., and Chaves, M. M. 2007. Deficit irrigation as a strategy to save water: Physiology and potential application to horticulture. J. Integr. Plant Biol. 49:1421-1434.

Davies, M. J., Harrison-Murray, R., Atkinson, C. J., and Grant, O. M. 2016. Application of deficit irrigation to container-grown hardy ornamental nursery stock via overhead irrigation, compared to drip irrigation. Agric. Water Manage. 163:244-254.

Del Castillo Múnera, J., and Hausbeck, M. K. 2015. Integrating host resistance and plant protectants to manage Pythium root rot on geranium and snapdragon. HortScience 50:1319-1326.

Del Castillo Múnera, J., and Hausbeck, M. K. 2016. Characterization of Pythium species associated with greenhouse floriculture crops in Michigan. Plant Dis. 100:569-576.

DiLeo, M. V., Pye, M. F., Roubtsova, T. V., Duniway, J. M., Macdonald, J. D., Rizzo, D. M., and Bostock, R. M. 2010. Abscisic acid in salt stress predisposition to Phytophthora root and crown rot in tomato and chrysanthemum. Phytopathology 100:871-879.

dos Santos, T. P., Lopes, C. M., Rodrigues, M. L., De Souza, C. R., Maroco, J. P., Pereira, J. S., Silva, J. R., and Chaves, M. M. 2003. Partial rootzone drying: Effects on growth and fruit quality of field-grown grapevines (Vitis vinifera). Funct. Plant Biol. 30:663-671.

Duniway, J. 1976. Movement of zoospores of Phytophthora cryptogea in soils of various textures and matric potentials. Phytopathology 66:877-882.

Elliott, J., Deryng, D., Müller, C., Frieler, K., Konzmann, M., Gerten, D., Glotter, M., Flörke, M., Wada, Y., and Best, N. 2014. Constraints and potentials of future irrigation water availability on agricultural production under climate change. Proc. Natl. Acad. Sci. 111:3239-3244.

Erwin, D. C., and Ribeiro, O. K. 1996. Phytophthora Diseases Worldwide. American Phytopathological Society, St. Paul, MN.

Fedoroff, N., Battisti, D., Beachy, R., Cooper, P., Fischhoff, D., Hodges, C., Knauf, V., Lobell, D., Mazur, B., and Molden, D. 2010. Radically rethinking agriculture for the 21st century. Science 327:833-834.

Fry, A., and Martin, R. 2005. Water facts and trends. World Business Council for Sustainable Development 16.

Fulcher, A., and Fernandez, T. 2013. Sustainable Nursery Irrigation Management Series Part I. Water Use in Nursery Production. Bulletin W287, University of Tennessee, Knoxville, TN.

Granke, L., Windstam, S., Hoch, H., Smart, C., and Hausbeck, M. 2009. Dispersal and movement mechanisms of Phytophthora capsici sporangia. Phytopathology 99:1258-1264.

Hausbeck, M. K., and Lamour, K. H. 2004. Phytophthora capsici on vegetable crops: Research progress and management challenges. Plant Dis. 88: 1292-1303.

Howell, T. A. 2001. Enhancing water use efficiency in irrigated agriculture. Agron. J. 93:281-289. 
Knight, J., Owen, J. S., and White, S. A. 2017. The past, present and future of water for nursery crops. In: American Nurseryman. Grand View Media, Birmingham, AL.

Kuşçu, H., Turhan, A., and Demir, A. O. 2014. The response of processing tomato to deficit irrigation at various phenological stages in a sub-humid environment. Agric. Water Manage. 133:92-103.

Lamari, L. 2008. ASSESS 2.0: Image Analysis Software for Disease Quantification. American Phytopathological Society, St. Paul, MN.

Lamm, A. J., Warner, L. A., Taylor, M. R., Martin, E. T., White, S. A., and Fisher, P. 2017. Diffusing water conservation and treatment technologies to nursery and greenhouse. J. International Agricultural Extension Education 24:105-119.

Lea-Cox, J. 2012. Using Wireless Sensor Networks for Precision Irrigation Scheduling. InTech, Rijeka, Croatia.

Lea-Cox, J. D., Bauerle, W. L., Van Iersel, M. W., Kantor, G. F., Bauerle, T. L., Lichtenberg, E., King, D. M., and Crawford, L. 2013. Advancing wireless sensor networks for irrigation management of ornamental crops: An overview. HortTechnology 23:717-724.

Leonberger, A., Speers, C., Ruhl, G., Creswell, T., and Beckerman, J. 2013. A survey of Phytophthora spp. in midwest nurseries, greenhouses, and landscapes. Plant Dis. 97:635-640.

MacDonald, J. 1982. Effect of salinity stress on the development of Phytophthora root rot of chrysanthemum. Phytopathology 72:214-219.

McRoberts, N., Hughes, G., and Madden, L. 2003. The theoretical basis and practical application of relationships between different disease intensity measurements in plants. Ann. Appl. Biol. 142:191-211.

Newhook, F., Young, B., Allen, S., and Allen, R. 1981. Zoospore motility of Phytophthora cinnamomi in particulate substrates. J. Phytopathol. 101: 202-209.

Nuruddin, M. M., Madramootoo, C. A., and Dodds, G. T. 2003. Effects of water stress at different growth stages on greenhouse tomato yield and quality. HortScience 38:1389-1393.

Obreza, T., Pitts, D., Mcgovern, R., and Spreen, T. 1996. Deficit irrigation of micro-irrigated tomato affects yield, fruit quality, and disease severity. J. Prod. Agric. 9:270-275.

Parke, J. L., Knaus, B. J., Fieland, V. J., Lewis, C., and Grünwald, N. J. 2014. Phytophthora community structure analyses in Oregon nurseries inform systems approaches to disease management. Phytopathology 104:1052-1062.

Patanè, C., and Cosentino, S. 2010. Effects of soil water deficit on yield and quality of processing tomato under a Mediterranean climate. Agric. Water Manage. 97:131-138.

Piao, S., Ciais, P., Huang, Y., Shen, Z., Peng, S., Li, J., Zhou, L., Liu, H., Ma, Y., and Ding, Y. 2010. The impacts of climate change on water resources and agriculture in China. Nature 467:43-51.
Quesada-Ocampo, L., and Hausbeck, M. 2010. Resistance in tomato and wild relatives to crown and root rot caused by Phytophthora capsici. Phytopathology 100:619-627.

Ristaino, J., and Duniway, J. 1989. Effect of preinoculation and postinoculation water stress on the severity of Phytophthora root rot in processing tomatoes. Plant Dis. 73:349-352.

Ristaino, J., Respess, K., Sullivan, T., and Whittington, D. 1991. Influence of rainfall, drip irrigation, and inoculum density on the development of Phytophthora root and crown rot epidemics and yield in bell pepper. Phytopathology 81:922-929.

Rizzo, D. M., Garbelotto, M., and Hansen, E. M. 2005. Phytophthora ramorum: Integrative research and management of an emerging pathogen in California and Oregon forests. Annu. Rev. Phytopathol. 43:309-335.

Schwingle, B., Smith, J., and Blanchette, R. 2007. Phytophthora species associated with diseased woody ornamentals in Minnesota nurseries. Plant Dis. 91:97-102.

Shah, D., and Madden, L. 2004. Nonparametric analysis of ordinal data in designed factorial experiments. Phytopathology 94:33-43.

Shaner, G., and Finney, R. 1977. The effect of nitrogen fertilization on the expression of slow-mildewing resistance in Knox wheat. Phytopathology 67:1051-1056.

Silvar, C., Duncan, J., Cooke, D., Williams, N., Díaz, J., and Merino, F. 2005. Development of specific PCR primers for identification and detection of Phytophthora capsici Leon. Eur. J. Plant Pathol. 112:43-52.

Swett, C., Reynolds, G., and Gordon, T. 2018. Infection without wounding and symptomless shoot colonization of Pinus radiata by Fusarium circinatum, the cause of pitch canker. For. Pathol. 48:e2422.

Swett, C. L., Kirkpatrick, S. C., and Gordon, T. R. 2016. Evidence for a hemibiotrophic association of the pitch canker pathogen Fusarium circinatum with Pinus radiata. Plant Dis. 100:79-84.

Tyree, M., and Hammel, H. 1972. The measurement of the turgor pressure and the water relations of plants by the pressure-bomb technique. J. Exp. Bot. 23:267-282.

Vörösmarty, C. J., Mcintyre, P. B., Gessner, M. O., Dudgeon, D., Prusevich, A., Green, P., Glidden, S., Bunn, S. E., Sullivan, C. A., and Liermann, C. R. 2010. Global threats to human water security and river biodiversity. Nature 467:555-561.

Warfield, C., Hwang, J., and Benson, D. 2008. Phytophthora blight and dieback in North Carolina nurseries during a 2003 survey. Plant Dis. 92: 474-481.

Weiland, J. E. 2011. Influence of isolation method on recovery of Pythium species from forest nursery soils in Oregon and Washington. Plant Dis. 95: 547-553. 